\title{
FORMULATION AND CHARACTERIZATION OF SERUM COLLAGEN OF SEA CUCUMBER EXTRACT STICHOPUS HORRENS AS AN ANTIOXIDANT
}

\author{
SOFI NURMAY STIANI ${ }^{*}$, TARSO RUDIANA ${ }^{2}$, YUSUB SETIAWAN ${ }^{3}$, ETI SETYOWATI ${ }^{3}$, SOFIAN ANSORI ${ }^{4}$
}

${ }^{1}$ Sekolah Tinggi Ilmu Kesehatan Salsabila, Serang Banten, Jalan Raya Serang-Pandeglang KM 06, Curug Serang Banten 42211, Indonesia, ${ }^{2}$ Chemistry Study Program Faculty of Science, Pharmacy and Health, Universitas Mathla'ul Anwar Banten, Jalan Raya Labuan KM 23, Saketi Pandeglang Banten 42273, Indonesia, ${ }^{3}$ Pharmacy Study Program Faculty of Science, Pharmacy and health Universitas Mathla'ul Anwar Banten, Jalan Raya Labuan KM 23, Saketi Pandeglang Banten 42273, Indonesia, ${ }^{4}$ Fish Residues and Medicine Laboratory Fish Disease and Environment Examination Center (LP2IL) Serang, Banten 42167 Indonesia Email: sofia240586@gmail.com, arso.rudiana@gmail.com

Received: 25 Aug 2021, Revised and Accepted: 08 Oct 2021

\section{ABSTRACT}

Objective: The study was aimed to extract, formulate and characterize collagen extract of Stichopus horrens into serum preparations and decide antioxidant activity in powders and serum preparations.

Methods: The sea cucumber meat was extracted collagen in three stages, namely the pretreatment stage using $0.3 \mathrm{M} \mathrm{NaOH} \mathrm{solution} \mathrm{1:10} \mathrm{(w/v)} \mathrm{for}$ $48 \mathrm{~h}$, the hydrolysis step in the $0.3 \mathrm{M} \mathrm{1:10}$ acetic acid solution $(\mathrm{w} / \mathrm{v})$ for $48 \mathrm{~h}$, and the extraction stage with distilled water $1: 2(\mathrm{w} / \mathrm{v})$ for $2 \mathrm{~h}$ at $45^{\circ} \mathrm{C}$. The collagen extract was freeze-dried to obtain collagen powder. Collagen powder was characterized by HPLC and its antioxidant activity was determined using the DPPH method. Collagen powder formulated with extract variation of $0,0.5$ and $1 \%$. Evaluation of serum included organoleptic, homogeneity, stability of $\mathrm{pH}$ and viscosity as well as antioxidant activity.

Results: The results showed that collagen powder had a \% yield of $0.24 \%$, which consisted of the amino acids glycine, proline, alanine, and glutamic acid as the dominant amino acids. The \% Free radical inhibition of collagen powder at concentration of $5000 \mathrm{ppm}$ was $63.23 \%$. IC50 values were obtained at $4045.37 \mathrm{ppm}$. The stability test resulted in stable serum preparations without significant changes at $4{ }^{\circ} \mathrm{C}$ and $27^{\circ} \mathrm{C} \pm 2{ }^{\circ} \mathrm{C}$ storage temperatures.

Conclusion: The measurement of DPPH Radical reduction activity in the highest serum preparation was $1 \%$ extract with a value of $2.4 \%$.

Keywords: Serum, Collagen, Stichopus horrens, Antioxidant

(c) 2021 The Authors. Published by Innovare Academic Sciences Pvt Ltd. Thisis an open access article under theCC BYlicense (https://creativecommons.org/licenses/by/4.0/) DOI: https://dx.doi.org/10.22159/ijap.2021.v13s4.43854 Journal homepage: https://innovareacademics.in/journals/index.php/ijap

\section{INTRODUCTION}

Currently, the use of medicinal ingredients is not only derived from plants but marine life is also being developed because it has great potential as a source of medicinal ingredients. Sea cucumbers are one of the most potential marine resources. Approximately 53 species of sea cucumbers are found in Indonesia, there are 22 species that can be consumed, and 8 of them have a high market value. The 8 species are sand sea cucumbers (Holothuria scraba), milk sea cucumbers or koro (Holothuria nobilis and Holothuria fuscogilva), rock sea cucumbers (Actinopyga echinites), bilbao sea cucumbers (Actinopyga lecanora), lotong sea cucumbers (Actinopyga miliaris), cat's eye sea cucumber (Bohadschia argus) and pineapple sea cucumber (Theleonata ananas) [1].

Sea cucumbers have complete nutritional content due to often being referred as seabed ginseng and are used as supplements. The results of laboratory analysis showed that the dried sea cucumber extract contained up to $86.8 \%$ protein, $80 \%$ collagen, minerals, mucopolysaccharides, glucosaminoglycans (GAG), natural antiseptics, chondroitin, omega 3 , omega 6 , and omega 9 , as well as various amino acids [2].

The active ingredients in various types of sea cucumbers have been reported in various publications, including the antibacterial activity of the sea cucumber Cucumaria frondosa was detected in extracts mainly coelomocyte and eggs from Cucumaria frondosa and potential for discovery novel antibiotics [3], isolate from sea cucumber Psolus patogenicus are glycoside and patagonicoside $\mathrm{A}$ have the antifungal activity against fungus Cladosporium cucumerinum [4], isolation of arginine kinase enzyme in sea cucumber Stichopus japonicus was success cloned the gene for sea cucumber into an E. coli expression vector purified functional enzyme [5], the activity of serum amyloid A in sea cucumber Holothuria glaberrina can activation of the immune system [6], glycoside structure in sea cucumber Stichopus mollisto classify $S$. mollis in the new genus Australostichopus levin [7], and isolation of fucan sulfate in sea cucumber Stichopus japonicus as an inhibitor of osteoclastogenesis [8].

Previous research regarding hydrolyzed collagen derived from golden sea cucumbers has an antioxidant effect $\left(\mathrm{IC}_{50}\right.$ of $5.25 \pm 0.15 \mathrm{mg} / \mathrm{ml}$ ) [9] Other studies confirm that sea cucumbers are a source of collagen and need further research [10]. Collagen plays an important role in the food, cosmetic and pharmaceutical industries [11]. Collagen which is a connective tissue in bones and skin, can be used for skin beauty and can increase the regeneration of dead cells due to wounds so that it can accelerate healing. Therefore, sea cucumber extract can be used as a cosmetic ingredient and ointment to heal wounds [2].

Collagen is used in the cosmetic field as an active ingredient in skin care products with the function to increase skin moisture, prevent wrinkles, keep the skin from the bad effects of radiation and maintain elasticity. Collagen is a fibrillar protein and is suitable for connective tissues in the human body, both skin, joints, and bones. Due to its abundance in the body, its strength and relationship are directly proportional to skin aging. Collagen fibers are damaged over time, losing thickness and strength, which are closely related to the phenomenon of skin aging and aging [12]. The addition of collagen in cosmetic formulations is intended to replace damaged collagen due to environmental influences and age factors. The specialty of using collagen is related to the physicochemical characteristics of collagen, including non-toxicity, low antigenicity, biocompatible and biodegradable, making collagen the main source in medical applications [13]. Cosmetics have developed rapidly into various dosage forms that function to increase user comfort. One form of cosmetic dosage has been widely developed is topical serum. Serum is a gel with a lower viscosity. Serum has the advantage that it can provide a more comfortable effect and is easier to spread on the surface of the skin because its viscosity is not too high [14]. Based on this description, no research has been found regarding the serum from this sea cucumber using Stichopus horrens collagen as an antioxidant serum. This study aims to extract, formulate and 
characterize Stichopus horrens collagen extract into serum preparations that meet SNI requirements and decide antioxidant activity in powder and serum dosage forms.

\section{MATERIALS AND METHODS}

The materials and tools used are knife, analytical balance, beaker, erlenmeyer, stirrer, volumetric pipette, measuring cup, stirring rod, filter cloth, freeze dryer, spatula, test tube, micropipette, conical tube, vial, vortex, oven, microtube, $\mathrm{pH}$ meter, rotary viscometer (NDJ 5S), UV-Vis Spectrophotometer (ShimadzuUVmini-1240 Japan), HPLC (Water Corporation USA), and IR spectrophotometry (Bruker Tensor 37 German), Stichopus horrens from Sangiang beach, aquadest, DPPH (1,1diphenyl-2-picrylhydrazyl), $0.3 \mathrm{M} \mathrm{NaOH}, 0.3 \mathrm{M}$ acetic acid, methanol, natrosol, glycerin, DMDM hydantoin, ethoxydiglycol.

\section{Identification of sea cucumber Stichopus horrens}

The identification of Stichopus horrens sea cucumber was carried out at the School of Biological Science and Technology, ITB, Labtek V C Building Forestry Building, Jl. Let. Gen. retired. Dr. (Hc) Mashudi No.1, Sayang, Jatinangor, Sumedang Regency, west java.

\section{Collagen extraction}

Collagen extraction was carried out in three stages, namely the pretreatment stage using sodium hydroxide solution, the hydrolysis stage in acetic acid solution, and the extraction stage with distilled water. Sea cucumber meat of Stichopus horrens as much as $1000 \mathrm{~g}$ was soaked in $0.3 \mathrm{M}$ sodium hydroxide with a ratio of meat to solution $1: 10(\mathrm{w} / \mathrm{v})$ for $48 \mathrm{~h}$ to remove non-collagen protein then filtered and the filtrate is neutralized with water to a neutral $\mathrm{pH}$. The filtrate soaked in $0.3 \mathrm{M}$ acetic acid with a ratio of meat to solution $1: 10(\mathrm{w} / \mathrm{v})$ for $48 \mathrm{~h}$, followed by the neutralization process again until the $\mathrm{pH}$ was neutral. Last step was extraction using distilled water for $2 \mathrm{~h}$ at $45^{\circ} \mathrm{C}$ with a ratio of $1: 2(\mathrm{w} / \mathrm{v})$ sample to solvent. The results of extraction are obtained in the form of liquid collagen which is then freeze-dried [15].

\section{Characterization using HPLC and FTIR}

The amino acid composition was determined by HPLC (AOAC 1995) and FTIR analysis. The HPLC instrument was rinsed with eluent to be used for 2-3 h. The syringe that will be used is rinsed with distilled water. Amino acid analysis using HPLC consisted of 4 stages, namely:

\section{a. Making protein hydrolyzate}

The sample was weighed as much as 0.1 grams and crushed, the crushed sample was added with $5-10 \mathrm{ml}$ of $6 \mathrm{~N} \mathrm{HCl}$. The solution was heated in an oven at $100^{\circ} \mathrm{C}$ for $24 \mathrm{~h}$. This is done to remove gas or air present in the sample so as not to disturb the resulting chromatogram. After heating, the protein hydrolyzate was filtered using a millipore measuring 45 microns.

\section{b. Drying}

Drying The filter results were taken as much as $10 \mu \mathrm{l}$ and added 30 $\mu$ 国 of drying solution. Dryer solution made from a mixture of methanol, sodium acetate, and trimethylamine in a ratio of 2:2:1. After the sample is dried with a vacuum pump to speed up the process and prevent oxidation.

\section{c. Derivatization}

The derivatization solution was prepared from a mixture of methanol, picoiodothiocyanate, and trimethylamine solutions in a ratio of 3:3:4. The derivatization process is carried out so that the detector is easy to detect the compounds present in the sample. Further dilution was carried out by adding $10 \mathrm{ml}$ of $60 \%$ acetonitrile and $1 \mathrm{M}$ sodium acetate and then left for $20 \mathrm{~min}$, filtered again using a millipore measuring 45 microns. $30 \mu$ [ of derivatization solution was added to the drying product.

\section{d. Injection}

The filter results were taken as much as $20 \mu$ 回 to be injected into the HPLC FTIR analysis to determine the typical functional groups of collagen. $100 \mathrm{mg} \mathrm{KBr}$ and $2 \mathrm{mg}$ of the test sample were ground until smooth and well mixed in a mortar and then molded into a pellet mold. Measurements were made with the FTIR tool at wavenumbers between 4000-500 cm-1.

\section{Antioxidant activity test}

Antioxidant activity is decided using the DPPH method. $10 \mathrm{mg}$ of sample was dissolved in methanol p. a then made in series with concentrations 5000, 4000, 3000, 2000, and 1000 ppm. Each concentration series was inserted into the microplate as much as $160 \mu \mathrm{l}$, added to the DPPH solution $(0.3 \mathrm{mg} / \mathrm{ml})$ each $40 \mu \mathrm{l}$. The DPPH solution was prepared by dissolving $3 \mathrm{mg}$ of DPPH into $10 \mathrm{ml}$ of methanol p. a. Sample blanks were made by inserting $160 \mu \mathrm{l}$ of sample into the well and adding $40 \mu \mathrm{l}$ of methanol p. a. Negative control was made by adding $160 \mu \mathrm{l}$ of methanol p. a with $40 \mu \mathrm{l}$ of DPPH and $200 \mu \mathrm{l}$ of methanol p. a as a blank. Ascorbic acid was used as a positive control with a concentration series of $4 ; 2 ; 1$; and 0.5 $\mathrm{ppm}$. The microplate was incubated at room temperature for $30 \mathrm{~min}$ and the absorbance was read using a UV-Vis spectrophotometer at a wavelength $517 \mathrm{~nm}$.

\section{Serum preparation formula and test the antioxidant activity}

The serum was formulated by adding Stichopus horrens collagen extract with a concentration of $0.5 \%$ and $1 \%$ into the serum formula with a Natrosol concentration of $0.75 \%$. Testing of antioxidant activity was carried out using the DPPH method. The DPPH solution was made by weighing $0.002 \mathrm{~g}$ of DPPH then dissolved in $100 \mathrm{ml}$ of methanol to obtain $0.002 \%$ DPPH. Preparation of a sample solution by weighing $50 \mathrm{mg}$ of sample and dissolving in $10 \mathrm{ml}$ of methanol so that the concentration becomes $5000 \mathrm{ppm}$ and diluted to $4000 \mathrm{ppm}$. The antioxidant test using the DPPH method, added $5 \mathrm{ml}$ of DPPH stock solution into the sample tube and incubated for $30 \mathrm{~min}$ in a dark room. After that, the absorbance was measured using a UV-Vis spectrophotometer at a wavelength 516 $\mathrm{nm}$. The process of making serum preparations is carried out based on the formula design as shown in table 1.

Table 1: Serum dosage formulation

\begin{tabular}{llll}
\hline Material & Use & Composition (\%) & F II \\
\cline { 2 - 4 } & & F I & $0.5 \mathrm{~g}$ \\
Collagen Extract Stichopus horrens & Active substances & - & $0.75 \mathrm{~g}$ \\
Natrosol & Gelling agent & $0.75 \mathrm{~g}$ & $1 \mathrm{~g}$ \\
Glycerine & Humectants & $10 \mathrm{ml}$ & $0.75 \mathrm{~g}$ \\
DMDM hydantoin & Preservative & $0.5 \mathrm{ml}$ & $10 \mathrm{ml}$ \\
Ethoxydiglycol & Emulsifier & $2 \mathrm{ml}$ & $0.5 \mathrm{ml}$ \\
Aquadest & Solvent & Ad 100 & $2 \mathrm{ml}$ \\
\hline
\end{tabular}

\section{Physical evaluation of Stichopus horrens collagen extract serum preparations}

Physical evaluation and stability tests of serum preparations include organoleptic, homogeneity, $\mathrm{pH}$, viscosity. Then the antioxidant activity test was carried out on serum preparations of Stichopus horrens collagen extract using the DPPH method (positive control of vitamin C serum).

\section{Stability test}

The stability of the preparation was evaluated at $4{ }^{\circ} \mathrm{C} \pm 2{ }^{\circ} \mathrm{C}$ and 27 ${ }^{\circ} \mathrm{C} \pm 2{ }^{\circ} \mathrm{C}$ for one month by observing organoleptic, homogeneity, $\mathrm{pH}$, and viscosity measurements.

\section{1) Organoleptic test}

Organoleptic tests can be observed by determining changes in color, odor and texture that occur during 1 mo of storage [16]. 


\section{2) Homogeneity}

The serum preparation of Stichopus horrens collagen extract was placed between two slides and then observed for the presence of coarse particles or inhomogeneities under light [16].

\section{3) pH measurement}

$\mathrm{pH}$ measurement using a digital $\mathrm{pH}$ meter.

\section{4) Viscosity}

Viscosity measurements were carried out using a rotary viscometer with a rotational viscometer type (NDJ 5S). The preparation is put into a beaker and the appropriate spindle is lowered to the limit of the spindle immersed in the preparation, then the motor and spindle are turned on. The rotational speed is set at $60 \mathrm{rpm}$. The viscosity number shown on the display screen shows the viscosity value.

\section{RESULTS}

The sea cucumber samples used in this study were identified at the SITH ITB Zoological Museum. Based on the results of No. 1272/l1. C02.2/lL/2019 the analysis of the types of sea cucumbers in this sample is Stichopus horrens, family Stichopodidae.

The collagen extract obtained was in the form of a cloudy white collagen solution and a freeze dryer process was carried out so that the solid form was brownish in color with a cotton-like texture with a yield of $0,24 \%$. The extraction process is carried out by soaking with $\mathrm{NaOH}$ solution, causing sea cucumber meat to expand (swelling) so that it can dissolve non-collagen proteins in sea cucumber meat [17]. The addition of acetic acid will break the cross-linked strands in the collagen so that it dissolves the non-crosslinked collagen and the collagen can dissolve completely [18].

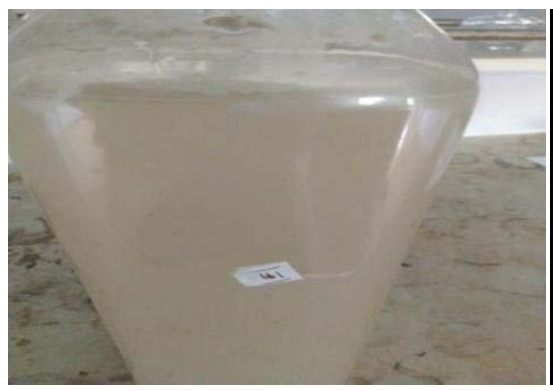

(a)

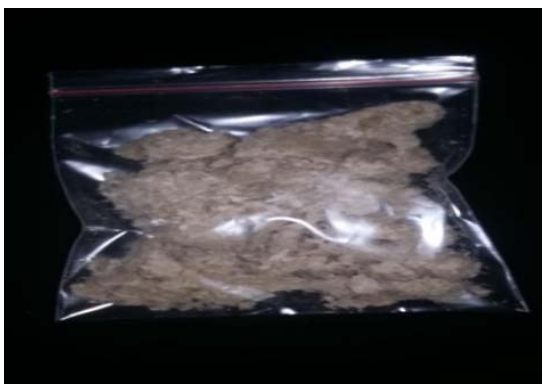

(b)

Fig. 1: a. Liquid extraction of collagen $b$. Collagen extract after freeze dryer

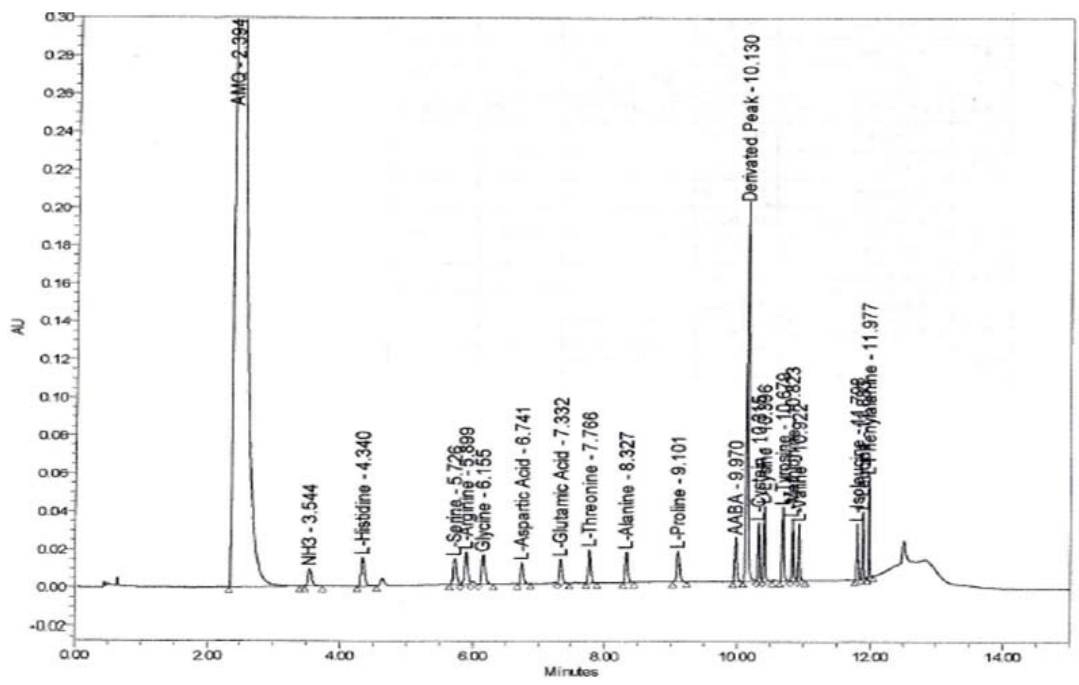

Fig. 2: HPLC chromatogram of sea cucumber collagen extract Stichopus horrens

Qualitative and quantitative analysis of amino acids using HPLC instruments. The results of the amino acid analysis of Stichopus horrens sea cucumber extract obtained 15 amino acid peaks consisting of 9 types of essential amino acids and 6 types of nonessential amino acids. The essential amino acids found in Stichopus horrens sea cucumbers are isoleucine, leucine, lysine, methionine, phenylalanine, histidine, threonine, valine, and arginine. The nonessential amino acids analyzed were aspartate, serine, glutamate, glycine, alanine, and tyrosine. The basic molecule of collagen is formed from three polypeptide chains that are twisted together to form a triple helix structure with a typical amino acid arrangement, namely Gly-XY, at position $\mathrm{X}$ is proline and $\mathrm{Y}$ is hydroxyproline. Interpretation peak can be seen in table 2 .
Based on table 2 shows that among the 15 amino acids obtained, three types of essential amino acids are dominated. There are arginine $3.76 \%$, leucine $1.27 \%$ and threonine $1.51 \%$, besides non-essential amino acids are dominated by glycine $8.29 \%$, proline $3.04 \%$, alanine $3.09 \%$ and glutamic acid $4.09 \%$. This study is in accordance with the results of previous research [19] who reported that glycine is an amino acid that is dominant in collagen and all families. Collagen is characterized by the presence of repeats of the amino acid sequence Gly-X-Y. Amino acids in the form of proline and hydroxyproline are important for the structural integrity of collagen because they plays an important role in the bond formation of intramolecular hydrogen [20]. 
Table 2: Composition of collagen amino acid content of sea cucumber Stichopus horrens

\begin{tabular}{lll}
\hline Amino acid & Retention time (Rt) & Concentration (\%) \\
\hline Aspartic acid & 6.799 & 2.660 \\
Glutamic acid & 7.377 & 4.890 \\
Glycine & 6.198 & 8.290 \\
histidine & 4.400 & 0.300 \\
Arginine & 5.946 & 3.760 \\
threonine & 7.798 & 1.510 \\
Alanine & 8.354 & 3.090 \\
Proline & 9.126 & 3.040 \\
Tyrosine & 10.370 & 0.750 \\
Valin & 10.896 & 1.070 \\
Methionine & 10.801 & 0.330 \\
Isoleucine & 11.759 & 0.870 \\
Leucine & 11.852 & 1.270 \\
Phenylalanine & 11.957 & 0.960 \\
Lysine & 10.370 & 0.470 \\
\hline
\end{tabular}

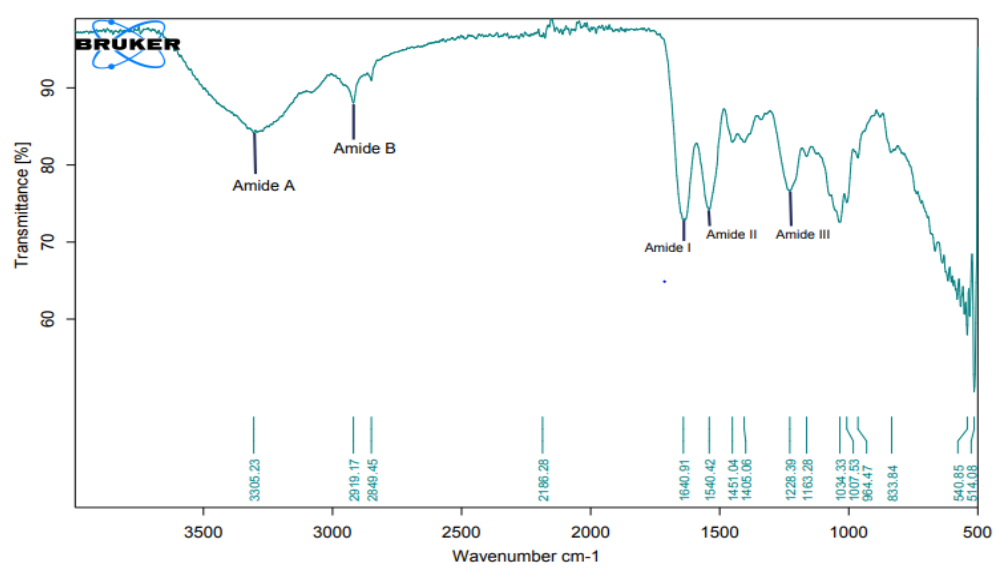

Fig. 3: FTIR spectrum of sea cucumber collagen extract Stichopus horrens

FTIR absorption peaks showed Stichopus horrens collagen has a distribution of absorption peaks at several wavenumbers indicating certain functional groups. The results of the analysis can be seen in table 3 .

Table 3: IR absorption of Stichopus horrens sea cucumber collagen extract

\begin{tabular}{llll}
\hline Wavenumber $\left(\mathbf{c m}^{-1}\right)$ & Absorption region $\mathbf{( c m})$ & Group & Type of compound \\
\hline 3305.23 & $3300-3500$ & OH & Alcohol \\
2919.11 & $2850-3000$ & $\mathrm{C}-\mathrm{H}$ & Alkanes \\
1640.91 & $1640-1680$ & $\mathrm{C}=\mathrm{C}$ & Alkene \\
1540.42 & $1500-1600$ & $\mathrm{C}=\mathrm{C}$ & Aromatic \\
1228.39 & $1180-1360$ & $\mathrm{~N}-\mathrm{H}$ & \\
1163.28 & $1080-1300$ & $\mathrm{C}=\mathrm{O}$ & Amine, aldehydes, esters, carboxylic acids and ketones \\
\hline
\end{tabular}

The functional group can be known by FTIR spectroscopy analysis of collagen extract of Stichopus horrens sea cucumbers in table 3, showing the absorption peaks of amide A, amide B, amide I, amide II and amide III (fig. 3). amide I has an absorption region in the range of $1600-1690 \mathrm{~cm}^{-1}$ which shows the stretching vibration of $\mathrm{C}=0$. The frequency of the amide I wavenumber is related to the secondary structure of the protein. Amide I consists of four components of the secondary structure of proteins there are-helix,-sheet,-turn, and random coils that overlap each other [21].

Percentage inhibition of free radical activity of the collagen extract of Stichopus horrens sea cucumber was carried out at a concentration series of 5000, 4000, 3000, 2000, 1000, 500 ppm with DPPH solution as a radical source. The test results can be seen in table 4 .

Table 4: Reduction activity of DPPH radical

\begin{tabular}{llll}
\hline Sample & Concentration (ppm) & Absorbance (ppm) & \% Inhibition \\
\hline Extract & 5000 & 0.076 & 69.230 \\
Collagen & 4000 & 0.132 & 46.560 \\
Sea cucumber & 3000 & 0.167 & 32.390 \\
Stichopus horrens & 2000 & 0.217 & 12.150 \\
Vitamin C & 1000 & 0.254 & 0.810 \\
& 4 & 0.012 & 86.046 \\
& 2 & 0.086 & 57.747 \\
& 1 & 0.182 & 20.175 \\
& 0.5 & 0.228 & 11.969 \\
\hline
\end{tabular}


Based on the calculations, the IC50 value is $4045.37 \mathrm{ppm}$ which indicates that the antioxidant activity is very weak. The results of this antioxidant test are better than the results of the $\mathrm{IC}_{50}$ tyrosinase enzyme study that showed that golden sea cucumber collagen has an IC50 value of $5610 \mathrm{ppm}$ [22]. The lower value IC50, showed the higher antioxidant activity. The difference in IC50 value is influenced by the amino acid content. Peptides containing total high hydrophobic amino acids (THAA) have high antioxidant activity to suppress oxidative reactions [23].

The results of the serum preparation of Stichopus horrens collagen extract, formula A produces a transparent color because, without extract, formula B is light brown with $0.5 \%$ collagen extract and formula $\mathrm{C}$ produces a dark brown serum with a concentration of $1 \%$ collagen extract (fig. 4).

Stability testing was carried out by storing the serum preparation of Stichopus horrens collagen extract at a low temperature of $4{ }^{\circ} \mathrm{C}$ and 27 ${ }^{\circ} \mathrm{C}$ at room temperature for $1 \mathrm{mo}$. Observation of the stability test included organoleptic examination, homogeneity, $\mathrm{pH}$, and viscosity.
The results of organoleptic observations of each serum preparation for one month at each temperature stability test did not show any significant changes in color and odor, only slightly thickened in the last week because it was influenced by storage temperature (table 5).

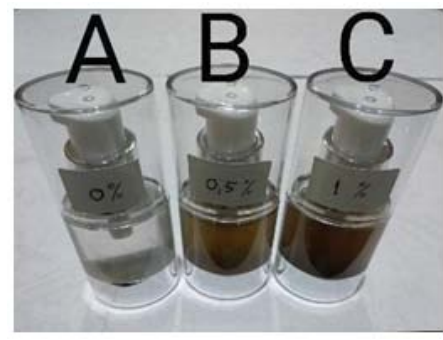

A. Formula $0 \%$,

B. Formula $0,5 \%$,

C. Formula $1 \%$

Fig. 4: Results of serum preparations of Stichopus horrens collagen extract

Table 5: Formulation of Stichopus horrens collagen extract

\begin{tabular}{|c|c|c|c|c|c|c|c|c|c|c|}
\hline \multirow[t]{2}{*}{ Time } & \multirow{2}{*}{$\begin{array}{l}\text { Temperature } \\
\left({ }^{\circ} \mathrm{C}\right)\end{array}$} & \multicolumn{3}{|l|}{ Formula 0\% } & \multicolumn{3}{|c|}{ Formula 0.5\% } & \multicolumn{3}{|c|}{ Formula 1\% } \\
\hline & & Color & $\begin{array}{l}\text { Smell } \\
\text { texture }\end{array}$ & Fragrant & Color & $\begin{array}{l}\text { Smell } \\
\text { texture }\end{array}$ & Fragrant & Color & $\begin{array}{l}\text { Smell } \\
\text { texture }\end{array}$ & Fragrant \\
\hline Week I & $\begin{array}{l}4 \\
27\end{array}$ & $\begin{array}{l}\text { Transparant } \\
\text { Transparant }\end{array}$ & $\begin{array}{l}\text { More viscous, } \\
\text { Smooth } \\
\text { Slightly thick, } \\
\text { Smooth }\end{array}$ & $\begin{array}{l}\text { Slightly } \\
\text { scented } \\
\text { Slightly } \\
\text { scented }\end{array}$ & $\begin{array}{l}\text { Light } \\
\text { brown } \\
\text { Light } \\
\text { brown }\end{array}$ & $\begin{array}{l}\text { Thicker, } \\
\text { smoother } \\
\text { Thick, } \\
\text { smooth }\end{array}$ & $\begin{array}{l}\text { Typical } \\
\text { smell } \\
\text { Typical } \\
\text { smell }\end{array}$ & $\begin{array}{l}\text { Dark } \\
\text { brown } \\
\text { Dark } \\
\text { brown }\end{array}$ & $\begin{array}{l}\text { Thicker, } \\
\text { smoother } \\
\text { Very thick, } \\
\text { smooth }\end{array}$ & $\begin{array}{l}\text { Typical of } \\
\text { the sea } \\
\text { Typical of } \\
\text { the sea }\end{array}$ \\
\hline $\begin{array}{l}\text { Week } \\
\text { II }\end{array}$ & $\begin{array}{l}4 \\
27\end{array}$ & $\begin{array}{l}\text { Transparant } \\
\text { Transparant }\end{array}$ & $\begin{array}{l}\text { More viscous, } \\
\text { Smooth } \\
\text { Slightly thick, } \\
\text { Smooth }\end{array}$ & $\begin{array}{l}\text { Slightly } \\
\text { scented } \\
\text { Slightly } \\
\text { scented }\end{array}$ & $\begin{array}{l}\text { Light } \\
\text { brown } \\
\text { Light } \\
\text { brown }\end{array}$ & $\begin{array}{l}\text { Thicker, } \\
\text { smoother } \\
\text { Thick, } \\
\text { smooth }\end{array}$ & $\begin{array}{l}\text { Typical } \\
\text { smell } \\
\text { Typical } \\
\text { smell }\end{array}$ & $\begin{array}{l}\text { Dark } \\
\text { brown } \\
\text { Dark } \\
\text { brown }\end{array}$ & $\begin{array}{l}\text { Thicker, } \\
\text { smoother } \\
\text { Very thick, } \\
\text { smooth }\end{array}$ & $\begin{array}{l}\text { Typical of } \\
\text { the sea } \\
\text { Typical of } \\
\text { the sea }\end{array}$ \\
\hline $\begin{array}{l}\text { Week } \\
\text { III }\end{array}$ & $\begin{array}{l}4 \\
27\end{array}$ & $\begin{array}{l}\text { Transparant } \\
\text { Transparant }\end{array}$ & $\begin{array}{l}\text { More viscous, } \\
\text { Smooth } \\
\text { Slightly thick, } \\
\text { Smooth }\end{array}$ & $\begin{array}{l}\text { Slightly } \\
\text { scented } \\
\text { Slightly } \\
\text { scented }\end{array}$ & $\begin{array}{l}\text { Light } \\
\text { brown } \\
\text { Light } \\
\text { brown }\end{array}$ & $\begin{array}{l}\text { Thicker, } \\
\text { smoother } \\
\text { Thick, } \\
\text { smooth }\end{array}$ & $\begin{array}{l}\text { Typical } \\
\text { smell } \\
\text { Typical } \\
\text { smell }\end{array}$ & $\begin{array}{l}\text { Dark } \\
\text { brown } \\
\text { Dark } \\
\text { brown }\end{array}$ & $\begin{array}{l}\text { Thicker, } \\
\text { smoother } \\
\text { Very thick, } \\
\text { smooth }\end{array}$ & $\begin{array}{l}\text { Typical of } \\
\text { the sea } \\
\text { Typical of } \\
\text { the sea }\end{array}$ \\
\hline $\begin{array}{l}\text { Week } \\
\text { IV }\end{array}$ & $\begin{array}{l}4 \\
27\end{array}$ & $\begin{array}{l}\text { Transparant } \\
\text { Transparant }\end{array}$ & $\begin{array}{l}\text { More viscous, } \\
\text { Smooth } \\
\text { Slightly thick, } \\
\text { Smooth }\end{array}$ & $\begin{array}{l}\text { Slightly } \\
\text { scented } \\
\text { Slightly } \\
\text { scented } \\
\end{array}$ & $\begin{array}{l}\text { Light } \\
\text { brown } \\
\text { Light } \\
\text { brown }\end{array}$ & $\begin{array}{l}\text { Thicker, } \\
\text { smoother } \\
\text { Thick, } \\
\text { smooth }\end{array}$ & $\begin{array}{l}\text { Typical } \\
\text { smell } \\
\text { Typical } \\
\text { smell } \\
\end{array}$ & $\begin{array}{l}\text { Dark } \\
\text { brown } \\
\text { Dark } \\
\text { brown } \\
\end{array}$ & $\begin{array}{l}\text { Thicker, } \\
\text { smoother } \\
\text { Very thick, } \\
\text { smooth }\end{array}$ & $\begin{array}{l}\text { Typical of } \\
\text { the sea } \\
\text { Typical of } \\
\text { the sea }\end{array}$ \\
\hline
\end{tabular}

Homogeneity test is an important factor for uniformity of content and patient comfort in using the preparation. Based on the results of these observations do not appear coarse grains (table 6-9).

Table 6: Results of homogeneity of $\mathrm{pH}$ at $4^{\circ} \mathrm{C}$ and $27^{\circ} \mathrm{C}$

\begin{tabular}{lllll}
\hline Formulation & Temperature $\left({ }^{\circ} \mathbf{C}\right)$ & Week I & Week II & Week III \\
\hline Formula 0\% (Base) & 4 & homogeneous & homogeneous & homogeneous \\
& 27 & homogeneous & homogeneous & homogeneous \\
Formula $0,5 \%$ & 4 & homogeneous & homogeneous & homogeneous \\
& 27 & homogeneous & homogeneous & homogeneous \\
Formula $1 \%$ & 4 & homogeneous & homogeneous & homogeneous \\
& 27 & homogeneous & homogeneous & homogeneous \\
\hline
\end{tabular}

Table 7: Results of $\mathrm{pH}$ measurements at $4^{\circ} \mathrm{C}$ and $27^{\circ} \mathrm{C}$

\begin{tabular}{lllll}
\hline Formulation & Temperature $\left({ }^{\circ} \mathbf{C}\right)$ & Week I pH \pm SD & Week II pH \pm SD & Week III pH \pm SD \\
\hline $0 \%$ & 4 & $7.3 \pm 0.01$ & $7.3 \pm 0.01$ & $7.3 \pm 0.01$ \\
& 27 & $6.8 \pm 0.02$ & $6.4 \pm 0.01$ & $6.1 \pm 0.01$ \\
$0,5 \%$ & 4 & $6.9 \pm 0.01$ & $6.9 \pm 0.01$ & $6.8 \pm 0.02$ \\
& 27 & $6.4 \pm 0.01$ & $6.2 \pm 0.01$ & $5.6 \pm 0.02$ \\
$1 \%$ & 4 & $6.8 \pm 0.01$ & $6.7 \pm 0.01$ & $6.6 \pm 0.02$ \\
& 27 & $6.3 \pm 0.01$ & $6.1 \pm 0.01$ & $5.9 \pm 0.02$ \\
\hline
\end{tabular}

Data represented as mean $\pm \mathrm{SD}(\mathrm{n}=2) * \mathrm{SD}=$ standard deviation 
Table 8: Viscosity measurement results at temperatures of $4{ }^{\circ} \mathrm{C}$ and $27^{\circ} \mathrm{C}$

\begin{tabular}{lllll}
\hline Formulation & Temperature $\left({ }^{\circ} \mathbf{C}\right)$ & Week I (cPs) & Week II (cPs) & Week III (cPs) \\
\hline $0 \%$ & 4 & $290 \pm 7.07$ & $1190 \pm 42.42$ & $790 \pm 14.14$ \\
& 27 & $240 \pm 14.14$ & $220 \pm 28.28$ & $250 \pm 35.35$ \\
$0,5 \%$ & 4 & $1280 \pm 14.14$ & $3050 \pm 70.71$ & $2740 \pm 56.56$ \\
& 27 & $1439 \pm 15.55$ & $1100 \pm 141.42$ & $1030 \pm 33.94$ \\
$1 \%$ & 4 & $2220 \pm 28.28$ & $4590 \pm 141.42$ & $370 \pm 42.42$ \\
& 27 & $2100 \pm 14.14$ & $2050 \pm 141.42$ & $1180 \pm 113.14$ \\
\hline
\end{tabular}

Data represented as mean $\pm \mathrm{SD}(\mathrm{n}=2) * \mathrm{SD}=$ standar deviation

Table 9: Reduction activity of DPPH radical

\begin{tabular}{|c|c|c|c|c|}
\hline Code/concentration & Replication & Abs blank & Abs sample & $\begin{array}{l}\text { Abs blank abs sample percent inhibition = (Blank abs- } \\
\text { sample } \mathrm{Abs} \text { )/sample Abs } \times 100 \%\end{array}$ \\
\hline $0 \%$ & 1 & 0.252 & 0.251 & 0.3968 \\
\hline $4000 \mathrm{ppm}$ & 2 & 0.255 & 0.251 & 1.5686 \\
\hline Average \pm SD & & & & $0.9827 \pm 0.8286$ \\
\hline $0,5 \%$ & 1 & 0.247 & 0.242 & 2.0243 \\
\hline $4000 \mathrm{ppm}$ & 2 & 0.253 & 0.247 & 2.3715 \\
\hline Average \pm SD & & & & $2.1979 \pm 0.2455$ \\
\hline $1 \%$ & 1 & 0.253 & 0.247 & 2.3715 \\
\hline $4000 \mathrm{ppm}$ & 2 & 0.247 & 0.241 & 2.4291 \\
\hline Average \pm SD & & & & $2.4003 \pm 0.0407$ \\
\hline
\end{tabular}

In this research, we have succeeded in formulating sea cucumbers into serum preparations that meet SNI 16-4399-1996 based on physical properties test, only for the antioxidant activity is very weak so it needs an increase in the concentration of the active substance and it is necessary to hydrolyze collagen before formulation so that it has the opportunity to have good antioxidant activity.

\section{DISCUSSION}

The sea cucumber samples were identified with the aim of proving the correctness of the materials used in the study. Fresh sea cucumber meat Stichopus horrens was cut into small pieces to facilitate the extraction process. The smaller the sample size, the solvent will be easily penetrated into the cells due to the target compound being extracted and dissolved in the solvent. The deproteinization process uses $0.3 \mathrm{~N} \mathrm{NaOH}$, which is to remove noncollagen proteins, fats, minerals, and pigments present in sea cucumber meat. During immersion in $\mathrm{NaOH}$ allows water to enter and causes non-collagenous proteins trapped in the collagen matrix to be more easily released. After pretreatment, the samples were washed with distilled water until the $\mathrm{pH}$ was close to neutral. The function of neutralization will reduce the remaining acid and base so that the resulting $\mathrm{pH}$ is close to neutral. The hydrolysis function uses $0.3 \mathrm{~N}$ acetic acid to change the structure of the collagen fibers into simpler fragments so as to facilitate the extraction process at a later stage. Soaking with distilled water after being immersed in a solution of $\mathrm{NaOH}$ or acetic acid is shown so that collagen has a $\mathrm{pH}$ close to neutral ( $\mathrm{pH}=7)$. The purpose of heating in the final stage is to form a water-soluble collagen triple helix structure and form a thick solution. The heating temperature does not exceed $45^{\circ} \mathrm{C}$ to avoid degradation of collagen to gelatin during extraction. The FTIR results show a typical functional group of collagen which is shown in the FTIR absorption region that at wavelength 3305.23 shows an $\mathrm{OH}$ group, at wave 2849.45 a $\mathrm{CH}$ group, at a wavelength of 1640.91 shows a $\mathrm{C}=\mathrm{C}$ group at a wavelength of 1540.42 it shows $\mathrm{C}=\mathrm{C}$ Aromatic 1163.28 is an ester group and at wave 1228.39 is an NH group. The criteria from the FTIR and HPLC results show a distinctive group of amino acids. The higher concentration of Stichopus horrens sea cucumber collagen extract resulted in a high percentage of free radical inhibition. In the extract of Stichopus horrens sea cucumber collagen based on the physical properties of collagen, the color of Stichopus horrens sea cucumber collagen is colorless after freeze dry, the color changes to brownish-white and has a cotton-like texture and has a $\mathrm{pH}$ of 6 according to the quality requirements of SNI 8076-2014 collagen, which has a pH of 6-7.5. The results of the $\mathrm{pH}$ examination of serum preparations showed that the $\mathrm{pH}$ value was in the range of 5.5-7.4. Formula 2 and 3 has a lower $\mathrm{pH}$ than Formula 1. This is due to the addition of the concentration of the active substance, namely collagen extract. Collagen extract is acidic so it can affect the $\mathrm{pH}$ of the preparation serum. Based on the results of $\mathrm{pH}$ measurements, it can be observed that the longer storage, the $\mathrm{pH}$ decreases. The decrease in $\mathrm{pH}$ can be caused by due to the presence of ionic contamination from the materials used in the formulations, either ion positive or negative ions that can affect acidity or basicity preparation. The serum $\mathrm{pH}$ in this experiment all formulas met the quality standard of SNI 16-4399-1996 for serum or sunscreen preparations was 4,5-8. The decrease or increase in the value of the viscosity can be caused by the influence of temperature, which causes a change in the polymer structure of the dosage base becomes more tenuous or denser so that more serum preparation is thick from the initial preparation. The effect of adding collagen extract also increases viscosity. The viscosity required by SNI is 2000-5000 cPs, in this experiment, the formula with the addition of $1 \%$ active substance meets the viscosity requirements.

\section{CONCLUSION}

Collagen powder had a $\%$ yield of $0.24 \%$, which consisted of the amino acids glycine, proline, alanine, and glutamic acid as the dominant amino acids. Collagen extracts can be used as serum preparations that meet SNI requirements. Collagen powder has a higher activity \% Free radical inhibition at a concentration of 5000 ppm at $63.23 \%$ with IC50 value is $4045,37 \mathrm{ppm}$ when compared to serum preparations with an extract concentration of $1 \%$ at $2,4 \%$.

\section{ACKNOWLEDGMENT}

We would like to thank Universitas Mathla'ul Anwar and STIKes Salsabila for supporting the funding of this research.

\section{FUNDING}

This research supported by Collaboration funding between Universitas Mathla'ul Anwar and STIKes Salsabila Serang, Indonesia.

\section{AUTHORS CONTRIBUTIONS}

All the authors contributed equally.

\section{CONFLICTS OF INTERESTS}

There are no conflicts of interest.

\section{REFERENCES}

1. Wiadnyana NN, Puspasari R, Mahulette RT. Resources status and fisheries of sea cucumbers in Indonesia: utilization and trade. J Policy Fish Indones. 2017;8:1-12. 
2. Suryaningrum TD. Sea cucumbers: Its potential as a nutraceutical ingredient and its processing technology. Squalen Bull Mar Fish Postharvest Biol Technol. 2008;3:63-9.

3. Haug T, Kjuul AK, Styrvold OB, Sandsdalen E, Olsen ØM, Stensvag K. Antibacterial activity in strongylocentrotus droebachiensis (Echinoidea), cucumaria frondosa (Holothuroidea), and asterias rubens (Asteroidea). J Invertebr Pathol. 2002;81(2):94-102. doi: 10.1016/s0022-2011(02)00153-2, PMID 12445793.

4. Murray AP, Muniain C, Seldes AM, Maier MS. Patagonicoside A: A novel antifungal disulfated triterpene glycoside from the sea cucumber Psolus patagonicus. Tetrahedron. 2001;57(47):9563-8. doi: 10.1016/S0040-4020(01)00970-X.

5. Guo SY, Guo Z, Guo Q, Chen BY, Wang XC. Expression, purification, and characterization of arginine kinase from the sea cucumber Stichopus japonicus. Protein Expr Purif. 2003;29(2):230-4. doi: 10.1016/s1046-5928(03)00013-5, PMID 12767814.

6. Santiago Cardona PG, Berrios CA, Ramirez F, Garcia Arraras JE. Lipopolysaccharides induce intestinal serum amyloid a expression in the sea cucumber holothuria glaberrima. Dev Comp Immunol. 2003;27(2):105-10. doi: 10.1016/s0145305x(02)00068-x, PMID 12543124.

7. Moraes G, Norhcote PC, Kalinin VI, Avilov SA, Silchenko AS, Dmitrenok PS, Stonik VA, Levin VS. Structure of the major triterpene glycoside from the sea cucumber stichopus mollis and evidence to reclassify this species into the new genus Australostichopus. Biochem Syst Ecol. 2004;32(7):637-50. doi: 10.1016/j.bse.2004.02.005.

8. Kariya Y, Mulloy B, Imai K, Tominaga A, Kaneko T, Asari A, Suzuki K, Masuda H, Kyogashima M, Ishii T. Isolation and partial characterization of fucan sulfates from the body wall of sea cucumber stichopus japonicus and their ability to inhibit osteoclastogenesis. Carbohydr Res. 2004;339(7):1339-46. doi: 10.1016/j.carres.2004.02.025, PMID 15113672.

9. Fawzya YN, Putra NA, Witarto AB, Patantis G. Golden sea cucumber: identification and the antioxidant activity of its collagen hydrolysates. Squalen Bull Mar Fish Postharvest Biol Technol. 2020;15:119-29.

10. Kumayanjati B. Teripang sebagai salah satu sumber kolagen. Oseana. 2020;45(1):17-27. doi: 10.14203/ oseana.2020.Vol.45No.1.51.

11. Kurnianto D, Indriana LF, Wahab A, Hafid S, Badi BF. Growth and survival of the juvenile sand sea cucumber Holothuria scabra on care with and without seaweed Gracilaria sp., using floating cages and sticking cages in ponds. OLDI (Oseanologi dan Limnol. di Indonesia. 2020;5:199-208.
12. Avila Rodriguez MI, Rodriguez Barroso LG, Sanchez ML. Collagen: a review on its sources and potential cosmetic applications. J Cosmet Dermatol. 2018;17(1):20-6. doi: 10.1111/jocd.12450, PMID 29144022.

13. Lee $\mathrm{CH}$, Singla A, Lee Y. Biomedical applications of collagen. Int J Pharm. 2001;221(1-2):1-22. doi: 10.1016/s03785173(01)00691-3, PMID 11397563.

14. Farmawati N, Anwar E, Azizahwati. Formulation of tyrosinase inhibiting serum-containing phytosomes longan seed extract (Dimocarpus longan lour.) using casein Coprocessed excipientxanthan gum. Faculte Pharms, University Indonesia; 2014.

15. Alhana A, Suptijah P, Tarman K. Extraction and characterization of collagen from sea cucumber flesh. JPHPI. 2015;18(2):150-61. doi: 10.17844/jphpi.2015.18.2.150.

16. Ayusida A. The formulation of the nanocollagen-based cream for sea cucumber gamma (Stichopus variegatus). Bogor: Institut Pertan; 2016.

17. Potaros T, Raksakulthai N, Runglerdkreangkrai J, Worawattanamateekul W. Characteristics of collagen from nile tilapia (Oreochromis niloticus) skin isolated by two different methods. Kasetsart J Nat Sci. 2009;43:584-93.

18. Liu D, Wei G, Li T, Hu J, Lu N, Regenstein JM, Zhou P, et al. Effects of alkaline pretreatments and acid extraction conditions on the acid-soluble collagen from grass carp (Ctenopharyngodon idella) skin. Food Chem. 2015;172:836-43. doi: 10.1016/j.foodchem.2014.09.147, PMID 25442628.

19. Yu D, Chi CF, Wang B, Ding GF, Li ZR. Characterization of acidand pepsin-soluble collagens from spines and skulls of skipjack tuna (Katsuwonus pelamis). Chin J Nat Med. 2014;12(9):712-20. doi: 10.1016/S1875-5364(14)60110-2, PMID 25263986.

20. Chi CF, Wang B, Li ZR, Luo HY, Ding GF, Wu CW. Characterization of acid-soluble collagen from the skin of hammerhead shark (Sphyrna lewini). J Food Biochem. 2014;38(2):236-47. doi: 10.1111/jfbc.12042.

21. Muyonga JH, Cole CGB, Duodu KG. Fourier transform infrared (FTIR) spectroscopic study of acid-soluble collagen and gelatin from skins and bones of young and adult Nile perch (Lates niloticus). Food Chem. 2004;86(3):325-32. doi: 10.1016/j.foodchem.2003.09.038.

22. Safithri M, Setyaningsih I, Tarman K, Yuhendri VM, Meydia M. Potential of golden collagen As A tyrosinase inhibitor. J Indonesian Fish Prod Processor. 2018;21:295-303.

23. Zhuang YL, Sun LP. Anti-melanogenic activities of collagen peptides from jellyfish (Stomolophus meleagris). Adv Mater Res. 2012;343-344:505-12. 10.4028/www.scientific.net/AMR.343-344.505. 